\title{
Copper metabolism in growing sheep given kale (Brassica oleracea) and ryegrass (Lolium perenne)-clover (Trifolium repens) fresh forage diets
}

\author{
BY T. N. BARR Y', K. R. MILLAR ${ }^{2}$, G. BOND² AND S. J. DUNCAN \\ 1 Invermay Agricultural Research Centre, Mosgiel, New Zealand \\ 2 Wallaceville Research Centre, Upper Hutt, New Zealand
}

(Received 26 November 1982 - Accepted 16 March 1983)

1. Kale (Brassica oleracea) and ryegrass (Lolium perenne)-clover (Trifolium repens) pasture grown under similar soil conditions were grazed in the vegetative state by growing lambs of $23.6 \mathrm{~kg}$ initial live weight for 24 weeks. Forty-eight lambs grazed each forage. The kale and pasture contained respectively 4 and $14 \mathrm{mg}$ copper $/ \mathrm{kg}$ dry matter (DM), 7.2 and $3.1 \mathrm{~g}$ total sulphur $/ \mathrm{kg} \mathrm{DM}$ and 0.4 and $1.1 \mathrm{mg}$ molybdenum $/ \mathrm{kg} \mathrm{DM}$.

2. Subcutaneous injections of $\mathrm{Cu}(12 \mathrm{mg})$ were given to half the animals grazing each forage during weeks 1 , 6,12 and 18.

3. All ninety-six animals were slaughtered at the end of the experiment and an additional group of twelve animals was slaughtered when the experiment commenced. Liver $\mathrm{Cu}$ was determined on all slaughtered animals and heart muscle cytochrome oxidase $(E C$ 1 9.3 .1$)$ activity on those slaughtered at week 24 . Blood samples removed at 6-week intervals were assayed for activity of superoxide dismutase (EC 1.15.1.1; SOD) and serum $\mathrm{Cu}$ concentration determined. Wool growth, live-weight gain and cytochrome oxidase activity of biopsied hind-limb muscle were also measured at 6-week intervals.

4. Control animals grazing pasture showed an accumulation of total liver $\mathrm{Cu}$ during the experiment. Animals grazing this diet and given $\mathrm{Cu}$ injections showed an additional accumulation of liver $\mathrm{Cu}$ equivalent to the supplementary $\mathrm{Cu}$ administered, but $\mathrm{Cu}$ supplementation did not affect the activity of any of the $\mathrm{Cu}$-containing enzymes measured and did not affect live-weight gain or wool growth.

5. Control animals grazing kale showed a depletion of total liver $\mathrm{Cu}$ and reductions in serum $\mathrm{Cu}$ concentrations during weeks 18 and 24 . However, cytochrome oxidase activity in heart and hind-limb muscle was similar to that of pasture-fed lambs. Blood SOD activity was reduced by kale feeding, but a laboratory study showed this enzyme was not inactivated by dimethyl disulphide produced from rumen fermentation of S-methyl-L-cysteine sulphoxide (SMCO) which occurs in kale.

6. $\mathrm{Cu}$ supplementation of kale-fed lambs had no effect on hind-limb cytochrome oxidase activity, but considerably increased total cytochrome oxidase activity in the heart and minimized the reduction in blood SOD activity. Both are considered to represent defence mechanisms against the haemolytic anaemia caused by SMCO. However, $\mathrm{Cu}$ supplementation did not affect live-weight gain or wool growth.

7. The proportion of injected $\mathrm{Cu}$ not recovered in the liver at slaughter was greater for lambs grazing kale than ryegrass-clover pasture and the same result was calculated from Barry et al. (1981) for growing cattle. It was therefore concluded that $\mathrm{Cu}$ requirements must be greater for growing sheep and cattle grazing kale than ryegrass-clover pasture.

Kale (Brassica oleracea) contains low concentrations of copper (4 mg/ $\mathrm{kg}$ dry matter (DM)) and high concentrations of sulphur $(8 \mathrm{~g} / \mathrm{kg} \mathrm{DM})$. Cattle given kale for longer than 12 weeks showed severe $\mathrm{Cu}$ deficiency, characterized by complete depletion of liver $\mathrm{Cu}$, depressions in $\mathrm{Cu}$ concentration in serum and in erythrocytes and reduced live-weight gain (Barry et al. 1981). Haemolytic anaemia, caused by rumen fermentation of S-methyl-L-cysteine sulphoxide (SMCO), which occurs in all brassica plants (Smith, 1974), was more severe in $\mathrm{Cu}$-deficient than $\mathrm{Cu}$-supplemented cattle given kale. Suttle (1976) has defined $\mathrm{Cu}$ deficiency as a three-stage process: first $\mathrm{Cu}$ depletion from storage sites (liver), followed by a depression in transport forms (plasma or serum $\mathrm{Cu}$ ) and finally reductions in $\mathrm{Cu}$ concentration at critical sites (Cu-containing enzymes) with the latter being associated with depressions in animal productivity. In the present study the critical sites selected were muscle cytochrome oxidase $(E C 1.9 .3 .1)$ and erythrocyte superoxide dismutase $(E C$ 1.15.1.1; 
SOD). Because the three-stage depletion process can delay the onset of deficiency symptoms when animals are transferred to a diet low in available $\mathrm{Cu}$, the present study was designed to be of long duration ( 24 weeks).

Objectives of the present investigation were to examine the effects of long-term kale-feeding upon the depletion, metabolism and response to supplementation of $\mathrm{Cu}$ in growing lambs. The content of many trace elements in forages is influenced by soil conditions under which the plants are grown as well as by the type of plant cultivar (Underwood, 1977). To differentiate between the two effects a second group of lambs grazed ryegrass (Lolium perenne)-clover (Trifolium repens) pasture grown under similar soil conditions as the kale and were subjected to the same experimental conditions.

\section{EXPERIMENTAL}

\section{Experimental design}

A $2 \times 2 \times 2$ factorial experiment was conducted utilizing two diets (kale and ryegrass-clover pasture), two levels of $\mathrm{Cu}$ supplementation (with and without) and two levels of iodine supplementation (with and without). The forty-eight lambs allocated to each diet were divided into groups of twelve and given $\mathrm{Cu}$ and iodine injections in a factorial arrangement. There were no $\mathrm{Cu} \times \mathrm{I}$ interactions $(P>0.05)$ and effects of I supplementation have been reported previously (Barry et al. 1983). Animals grazed the two forages for 24 weeks and all were slaughtered at the end of the experiment. An initial slaughter (IS) group of twelve lambs was slaughtered at the start of the experiment so that the initial concentration and total amount of $\mathrm{Cu}$ in the liver could be determined. The experiment commenced in midsummer and was concluded during winter; most of the pasture used was therefore autumn grown.

\section{Forages and animals}

The forages used, grazing management, animals and slaughter procedures were as described by Barry et al. (1983). Initial live weight of the lambs was $23.6 \mathrm{~kg}$ (SD $2.2 \mathrm{~kg}$ ). Live-weight gains were calculated from weighing after 24 -h fasts and wool growth measured by clipping $122.5 \times 122.5 \mathrm{~mm}$ mid-side areas to skin level. Both were recorded at 6-week intervals. $\mathrm{Cu}$ was administered by subcutaneous injection of $\mathrm{Cu}-\mathrm{Ca}$ ethylene diamine tetra-acetate (Glaxo Laboratories (NZ) Ltd) during weeks 1, 6, 12 and 18. Each injection supplied $12 \mathrm{mg} \mathrm{Cu}$. Selenium was administered orally $(2.5 \mathrm{mg})$ as sodium selenate 3 weeks before the experiment commenced and also during week 12. Iodine was administered during weeks 1 and 12 by intramuscular injection of $1 \mathrm{ml}$ iodized oil supplying $475 \mathrm{mg}$ I per injection.

\section{Sampling procedures}

Samples of kale similar to what was eaten by the animals were collected at 4-week intervals and pasture at 2-week intervals using the procedures described by Barry et al. (1983). These were then freeze-dried. In all samplings for blood and muscle, the same animals were serially sampled throughout the experiment and in all cases each $\mathrm{Cu}$-treatment group sampled contained equal numbers of animals that had or had not received I supplementation.

Blood was withdrawn by venipuncture of the jugular vein during weeks $1,6,12,18$ and 24 , with sixteen of the twenty-four animals per $\mathrm{Cu}$-treatment group being sampled. The blood samples were taken $2 \mathrm{~h}$ before $\mathrm{Cu}$ injections were given. Whole blood was kept at $4^{\circ}$ and assayed for SOD activity within $48 \mathrm{~h}$, whilst serum was stored at $-20^{\circ}$ for $\mathrm{Cu}$ analysis. Livers and hearts from all IS and final-slaughter animals were minced and stored at $-20^{\circ}$. Before mincing, septum muscle samples (approximately $1 \mathrm{~g}$ ) were removed from forty-eight hearts of final slaughter animals (twelve per Cu-treatment group) and immediately assayed for cytochrome oxidase activity. 
Samples of hind-limb muscle were removed by biopsy from four animals per $\mathrm{Cu}$-treatment group of 24 at 6-week intervals for cytochrome oxidase assay. The animals were first treated with a tranquillizing and analgesic drug (Rompun; Bayer, West Germany) and then given a local anaesthetic at the site of the incision (Xylocaine; Astra Chemicals, Sydney). Muscle samples were then withdrawn by needle biopsy, after which the animals were given a broad-spectrum long-acting antibiotic (Penstrep; Rosco, Denmark).

\section{Laboratory methods}

Plant analysis, determination of $\mathrm{Cu}$ and iron in minced liver and heart tissue, and determination of blood haemoglobin concentration and Heinz-body counts were carried out as described by Barry et al. (1981).

Blood was prepared for SOD assay by the method of Minami \& Yoshikawa (1979), and SOD determined on the clear supernatant fraction at $25^{\circ}$ using the ability of the enzyme to inhibit the autoxidation of pyrogallol (Marklund \& Marklund, 1974). SOD, purified from bovine blood (Sigma Chemical Co., St Louis, MO) and containing 2500 units/mg protein, was used as a standard. The units used were as defined by McCord \& Fridovich (1969).

To investigate whether dimethyl disulphide, produced from rumen fermentation of SMCO, could inactivate SOD, in vitro experiments were conducted where dimethyl disulphide was added to either whole sheep blood or the final enzyme assay mixture to give concentrations of $0,10,25,50,75$ and $100 \mu \mathrm{M}$. SOD assays were then carried out. The range of concentrations encompassed those which occur in the blood of animals with brassica anaemia (20-50 $\mu \mathrm{M}$; Steven et al. 1981).

Homogenates of muscle $(5 \mathrm{~g} / 1)$ were prepared in Triton X-100 (2 g/1; Sigma Chemical Co.) and cytochrome oxidase activity determined by measuring the rate of oxidation of reduced cytochrome $\mathrm{c}$ by following the change in absorbance with time at $550 \mathrm{~nm}$ (Mills \& Dalgarno, 1970).

\section{Statistical methods}

Results were analysed using factorial analysis of variance, with the error term based on between-animal variability. For blood SOD, analyses carried out on values from the initial sampling revealed differences between animals allocated to some treatment groups $(P<0.05)$. Consequently, these values were analysed as differences from the initial value (mean 5177 units/g haemoglobin).

\section{RESULTS}

\section{Diet composition}

Kale contained much higher concentrations of total $S$ and sulphate $S$ than ryegrass-clover pasture and lower concentrations of $\mathrm{Cu}, \mathrm{Se}$ and $\mathrm{Mo}$ (Table 1).

\section{Liver $\mathrm{Cu}$ and $\mathrm{Fe}$}

After 24 weeks, both the concentration and the total amount of $\mathrm{Cu}$ in the liver (Table 2) were greater for animals grazing pasture than kale $(P<0.001)$ and were increased by $\mathrm{Cu}$ supplementation $(P<0.001)$. Relative to the IS group, control animals grazing kale for 24 weeks showed a reduction in total liver $\mathrm{Cu}$, whereas control animals grazing pasture showed a substantial increase in total liver $\mathrm{Cu}$. Liver $\mathrm{Fe}$ concentration did not differ between animals grazing kale or pasture for 24 weeks $(116 \mathrm{mg} / \mathrm{kg}$ fresh weight). 
Table 1. Chemical composition of the forage consumed

(Mean values and standard deviations for six kale samples taken at 4-weekly intervals and twelve pasture samples taken at 2-weekly intervals)

\begin{tabular}{|c|c|c|c|c|}
\hline & \multicolumn{2}{|c|}{ Kale* } & \multicolumn{2}{|c|}{ Pasture $\dagger$} \\
\hline & Mean & SD & Mean & SD \\
\hline Copper (mg/kg DM) & $4 \cdot 0$ & $1 \cdot 26$ & $14 \cdot 1$ & $5 \cdot 80$ \\
\hline Total sulphur (g/kg DM) & $7 \cdot 2$ & 0.71 & $3 \cdot 1$ & 0.20 \\
\hline Sulphate-S (g/kg DM) & $4 \cdot 0$ & 0.94 & 1.4 & 0.25 \\
\hline Molybdenum (mg/kg DM) & $0 \cdot 4$ & $0 \cdot 15$ & $1 \cdot 1$ & 0.87 \\
\hline Selenium $(\mu \mathrm{g} / \mathrm{kg} \mathrm{DM})$ & 27 & $12 \cdot 1$ & 45 & 10.0 \\
\hline
\end{tabular}

DM, dry matter.

* (Brassica oleracea.)

$\dagger$ Ryegrass (Lolium perenne)-clover (Trifolium repens).

Table 2. Concentration ( $\mathrm{mg} / \mathrm{kg}$ fresh weight) and total amount ( $\mathrm{mg}$ ) of copper in the liver of animals slaughtered at the beginning and end of the experiment

(Mean values with their standard errors for twelve initial animals and twenty-four animals per treatment group at final slaughter)

\begin{tabular}{|c|c|c|c|c|c|c|c|}
\hline \multirow[b]{3}{*}{$\mathrm{Cu}$} & \multirow{2}{*}{\multicolumn{2}{|c|}{$\begin{array}{l}\text { Initial slaughter } \\
\text { group (week 0) }\end{array}$}} & \multicolumn{5}{|c|}{ Final slaughter group (week 24) } \\
\hline & & & \multicolumn{2}{|c|}{ Kale* } & \multicolumn{2}{|c|}{ Pasture $\dagger$} & \multirow[b]{2}{*}{$\mathbf{S E}$} \\
\hline & Mean & $\mathrm{SE}$ & No $\mathrm{Cu}$ & $+\mathrm{Cu}$ & No $\mathrm{Cu}$ & $+\mathrm{Cu}$ & \\
\hline Liver concentration & 77 & $5 \cdot 1$ & 35 & 86 & 117 & 173 & $10 \cdot 6$ \\
\hline Liver total & 37 & $2 \cdot 9$ & 24 & 57 & 88 & 137 & 7.6 \\
\hline
\end{tabular}

\section{Serum $\mathrm{Cu}$ concentration}

In samples taken during weeks 1,6 and 12 , serum $\mathrm{Cu}$ concentration was unaffected by diet (Table 3). Lower values were recorded for animals grazing kale than for those grazing pasture during weeks 18 and $24(P<0 \cdot 01)$. Serum $\mathrm{Cu}$ concentration was unaffected by $\mathrm{Cu}$ supplementation at all the sampling times, but this could be a reflection of the samples being taken 6 weeks after the injections were given.

\section{Muscle cytochrome oxidase activity}

Cytochrome oxidase activity of hind-limb muscle was 5.6 and 7.0 units/mg wet muscle (SEM 0.49 and 0.52 respectively) during weeks 1 and 24 , and was unaffected by either diet or $\mathrm{Cu}$ supplementation.

Heart-muscle cytochrome oxidase activity was unaffected by $\mathrm{Cu}$ supplementation in animals grazing pasture (Table 4), and animals grazing kale that did not receive $\mathrm{Cu}$ supplementation showed similar values. $\mathrm{Cu}$ supplementation to animals grazing kale increased the total amount of cytochrome oxidase activity per heart $(P<0 \cdot 01)$, with part of the response due to a non-significant trend for $\mathrm{Cu}$ supplementation to increase heart-muscle cytochrome oxidase activity per unit muscle weight $(P<0 \cdot 10)$. Both effects were additive to those produced by I supplementation (Barry et al. 1983), with combinations of $\mathrm{Cu}$ and I producing the largest increases in total heart cytochrome oxidase content. The 
Table 3. Serum copper concentration $(\mathrm{mg} / \mathrm{l})$ determined at 6-weekly intervals

(Mean values with their standard errors for thirty-two animals per treatment group)

\begin{tabular}{cccc}
\hline & \multicolumn{2}{c}{ Diet } & \\
\cline { 2 - 4 } Stage of experiment (weeks) & Kale* & Pasture & SE \\
\hline 1 & 0.96 & 0.96 & 0.024 \\
6 & 0.80 & 0.87 & 0.030 \\
12 & 0.83 & 0.81 & 0.027 \\
18 & 0.73 & 0.84 & 0.022 \\
24 & 0.71 & 1.00 & 0.030 \\
\hline
\end{tabular}

* (Brassica oleracea.)

$\uparrow$ Ryegrass (Lolium perenne) - clover (Trifolium repens).

Table 4. Heart weight and cytochrome oxidase activity (EC 1.9.3.1; cytochrome c oxidized/min) and copper concentration in heart muscle, determined at the end of week 24

(Mean values with their standard errors for forty-eight animals grazing pasture and twelve animals per sub-group grazing kale)

\begin{tabular}{|c|c|c|c|c|c|c|c|}
\hline & \multicolumn{7}{|c|}{ Diet } \\
\hline & \multicolumn{5}{|c|}{ Kale* } & \multicolumn{2}{|c|}{ Pasture $\dagger$} \\
\hline & 0 & $+\mathrm{Cu}$ & $+I_{2}$ & $+\mathrm{Cu}+\mathrm{I}_{2}$ & $\mathbf{S E}$ & Mean & $\mathrm{SE}$ \\
\hline Heart weight (g) & 147 & 149 & 162 & 162 & $4 \cdot 1$ & 151 & $2 \cdot 1$ \\
\hline \multicolumn{8}{|l|}{$\begin{array}{l}\text { Cytochrome } \\
\text { oxidase } \\
\text { activity }\end{array}$} \\
\hline $\begin{array}{l}\text { (nmol/mg wet } \\
\text { muscle) }\end{array}$ & 43 & 50 & 51 & 58 & $2 \cdot 6$ & 40 & 1.8 \\
\hline & 5.9 & $7 \cdot 3$ & $7 \cdot 8$ & 9.9 & 0.41 & $6 \cdot 2$ & $0 \cdot 29$ \\
\hline \multirow{3}{*}{$\begin{array}{l}\text { Cu concentration } \ddagger \\
\text { (mg/kg wet } \\
\text { muscle) } \\
\text { (mg/heart) }\end{array}$} & & & & & & & \\
\hline & $7 \cdot 0$ & $6 \cdot 6$ & 6.8 & $5 \cdot 7$ & $1 \cdot 11$ & $6 \cdot 8$ & 0.79 \\
\hline & 1.04 & 0.93 & 1.09 & 0.94 & 0.196 & 1.07 & 0.139 \\
\hline
\end{tabular}

* (Brassica oleracea.)

$\dagger$ Ryegrass (Lolium perenne) - clover (Trifolium repens).

$\ddagger$ Heart muscle of initial slaughter group contained $5.4 \mathrm{mg} \mathrm{Cu} / \mathrm{kg}$ wet muscle (SEM 1.04 ) and $0.64 \mathrm{mg} \mathrm{Cu} / \mathrm{heart}$ (SEM 0-14).

concentration and total amount of $\mathrm{Cu}$ in heart muscle was unaffected by either diet or $\mathrm{Cu}$ supplementation.

\section{Heinz-body formation, blood haemoglobin concentration and SOD activity}

Lambs given the pasture diet showed some seasonal changes in blood composition as the experiment progressed, characterized by an increase in haemoglobin concentration, a decrease in SOD activity/g haemoglobin (Figs. 1 and 2) and an increase in the proportion of erythrocytes containing Heinz bodies from 0.002 to 0.053 . None of these criteria was affected by $\mathrm{Cu}$ supplementation.

In kale-fed lambs the proportion of erythrocytes containing Heinz bodies was 0.26-0.42 and blood haemoglobin concentration was lower for animals grazing kale than for those 


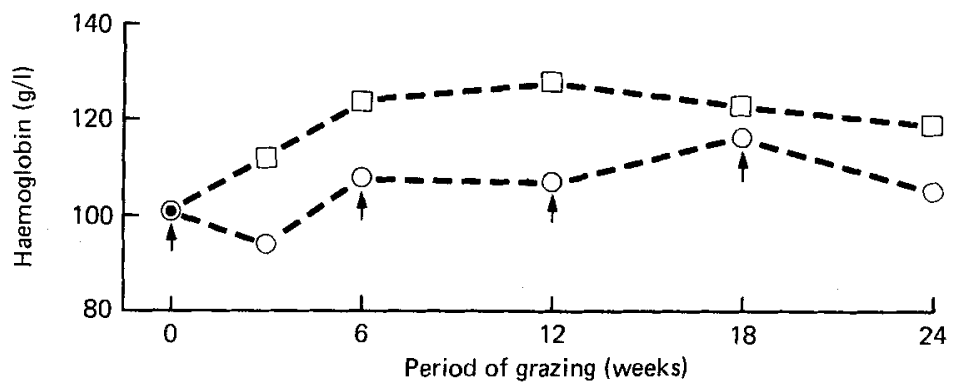

Fig. 1. Changes with duration of grazing for blood haemoglobin concentration in lambs grazing kale (Brassica oleracea) $(\mathrm{O})$ or ryegrass (Lolium perenne)-clover (Trifolium repens) pasture ( $\square$ ). Points are mean values for control and copper-supplemented animals. SEM values did not exceed $2 \cdot 0 \mathrm{~g} / 1$. $\uparrow$, Supplementation with $12 \mathrm{mg} \mathrm{Cu}$.

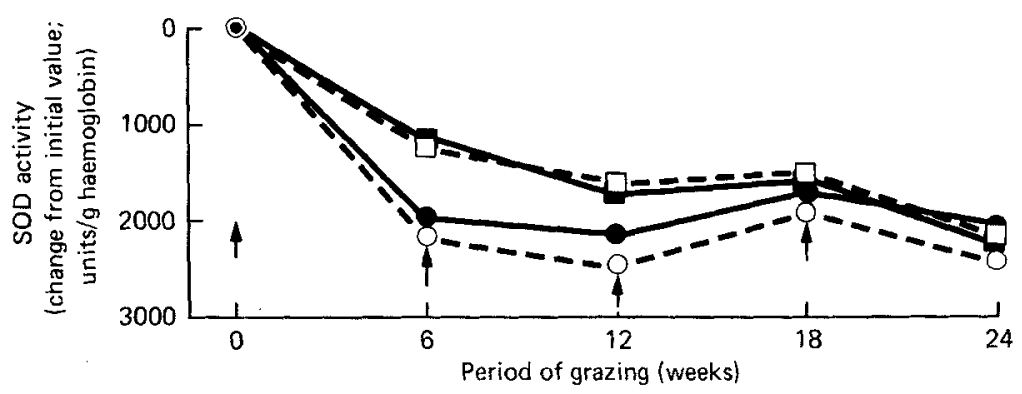

Fig. 2. Changes (from initial mean value of 5177 units/g haemoglobin) in superoxide dismutase (EC 1.15 .1 .1 ; SOD) activity with duration of grazing in lambs grazing kale (Brassica oleracea) $(O, O)$ or ryegrass (Lolium perenne)-clover (Trifolium repens) pasture $(\square, \square)$. Points are mean values for control $(O, \square)$ and copper-supplemented $(O, \square)$ animals. SEM values did not exceed $102 \mathrm{units} / \mathrm{g}$ haemoglobin. $\uparrow$, Supplementation with $12 \mathrm{mg} \mathrm{Cu}$.

grazing pasture $(P<0.001$; Fig. 1); neither was affected by $\mathrm{Cu}$ supplementation. Blood SOD activity of control animals given kale dropped to lower levels than for those given pasture during weeks 6 and 12, and then progressively recovered to attain similar values by week 24 (Fig. 2). Copper supplementation tended to increase blood SOD in animals grazing kale, with the difference attaining significance in weeks 12 and $24(P<0.05)$.

In the in vitro studies, dimethyl disulphide addition had no effect on SOD activity. Mean values were 235 units (SEM 3.4) when added to whole blood and 431 units (SEM 5.2) when added to the enzyme assay mixture.

\section{Live-weight gain and wool growth}

Live-weight gain over the full 24 weeks was $112 \mathrm{~g} / \mathrm{d}$ and was unaffected by either type of diet or $\mathrm{Cu}$ supplementation. Mid-side wool growth over 24 weeks was 99 and $118 \mathrm{mg} / 10^{4} \mathrm{~mm}^{2}$ per d (SED 3.1) for animals fed kale and pasture respectively $(P<0.001)$, and was unaffected by $\mathrm{Cu}$ supplementation.

\section{DISCUSSION}

\section{Depletion of $\mathrm{Cu}$ from liver and serum}

The changes in liver and serum $\mathrm{Cu}$ observed in the groups that did not receive $\mathrm{Cu}$ supplementation show some extent of $\mathrm{Cu}$ depletion from grazing kale and no depletion from grazing ryegrass-clover pasture. However, the depletion is considered very mild compared with that encountered in young cattle grazing kale for 24 weeks, where Cu concentrations 
in fresh liver and serum were reduced to $3 \mathrm{mg} / \mathrm{kg}$ and $0.3 \mathrm{mg} / \mathrm{l}$ respectively and liver $\mathrm{Fe}$ concentration elevated to $1200 \mathrm{mg} / \mathrm{kg}$ fresh weight (Barry et al. 1981).

\section{Critical sites of $\mathrm{Cu}$ action}

Relative to lambs grazing pasture, those grazing kale that did not receive supplementary $\mathrm{Cu}$ and I showed no reduction in cytochrome oxidase activity in either hind-limb muscle or heart muscle, in accord with the $\mathrm{Cu}$ depletion being only very mild. On the contrary, both $\mathrm{Cu}$ and $\mathrm{I}$ supplementation increased heart-muscle cytochrome oxidase activity to levels well above those found in lambs grazing pasture, and this has been suggested as a compensatory mechanism for the reduced blood oxygen-carrying capacity caused by haemolytic anaemia in lambs grazing kale (Barry et al. 1983).

Steven et al. (1981) found that dimethyl disulphide inactivated a range of enzymes. However, it was without effect on SOD in the present study and the cause of the rapid fall in SOD activity in kale-fed lambs remains unknown. Injection of $\mathrm{Cu}$ to $\mathrm{Cu}$-deficient rats increased SOD activity to normal values after $36 \mathrm{~h}$ (Bohenkamp \& Wesser, 1976), but in $\mathrm{Cu}$-deficient sheep $90 \mathrm{~d}$ of feeding on a $\mathrm{Cu}$-adequate diet was required (Andrewartha \& Caple, 1980). Also in the present study the full effects of $\mathrm{Cu}$ supplementation on elevating blood SOD activity of kale-fed lambs was not expressed until after $84 \mathrm{~d}$. A period of $90 \mathrm{~d}$ corresponds to the life-span of erythrocytes in lambs and it therefore seems that in sheep $\mathrm{Cu}$ attaches to SOD during erythropoiesis.

In erythrocytes, reduced glutathione (GSH) maintains the reducing environment necessary for haemoglobin stability. Dimethyl disulphide produced from rumen fermentation of SMCO in kale-fed ruminants inactivates erythrocyte GSH, leading to the precipitation of haemoglobin as Heinz bodies and to the development of haemolytic anaemia (Smith, 1974). As well as undergoing rapid dissociation to haemoglobin and $\mathrm{O}_{2}$, oxyhaemoglobin also undergoes slow dissociation to methaemoglobin and the superoxide anion (Misra \& Fridovich, 1972; Wever $e$ t al. 1973). SOD functions by removing the superoxide anion $\left(\mathrm{O}_{2}^{-}\right)$, thus preventing GSH from further inactivation. In the present investigation it seems that even in control kale-fed lambs, blood SOD activity must have been above the minimum level necessary to ensure protection of erythrocytes from $\mathrm{O}_{2}^{-}$, as $\mathrm{Cu}$ supplementation did not reduce Heinz-body counts or increase haemoglobin synthesis. However, the effect of $\mathrm{Cu}$ supplementation in increasing blood SOD offers a ready explanation for its effect in kale-fed cattle of reducing Heinz-body formation and allowing a much more rapid recovery in blood haemoglobin (Barry et al. 1981).

\section{Retention of supplementary $\mathrm{Cu}$ in the liver}

The proportion of supplementary injected $\mathrm{Cu}$ retained in the liver can readily be calculated as the difference in total liver $\mathrm{Cu}$ between injected and control animals grazing the same forage. In both the present investigation and an identical investigation with growing cattle (Barry et al. 1981), the proportion of injected $\mathrm{Cu}$ not recovered in the liver was greater for animals grazing kale than for those grazing ryegrass-clover pasture (Table 5). Injected $\mathrm{Cu}$ not recovered in the liver can be accounted for by a variety of functions, including endogenous $\mathrm{Cu}$ losses, net body $\mathrm{Cu}$ losses above endogenous $\mathrm{Cu}$ losses and additional $\mathrm{Cu}$ deposition in muscle or skeletal tissue. The present approach does not permit differentiation between these processes, but does show that $\mathrm{Cu}$ requirements of growing sheep and cattle grazing kale are greater than when they are grazing ryegrass-clover pasture by approximately $3 \mu \mathrm{g} / \mathrm{kg}$ live weight per $\mathrm{d}$. This is surprising as McDonald et al. (1979) showed that endogenous $\mathrm{Cu}$ losses are proportional to existing hepatic $\mathrm{Cu}$ reserves, and on this basis greater endogenous losses would be expected for animals grazing ryegrass-clover pasture than for those grazing kale. Effects of kale-feeding in increasing SOD destruction (blood), 
Table 5. Supplementary injected copper not retained in the liver, calculated from the difference in total liver copper between control and Cu-supplemented ruminants grazing kale (Brassica oleracea) or ryegrass (Lolium perenne)-clover (Trifolium repens) pasture for 24 weeks

\begin{tabular}{|c|c|c|c|c|}
\hline \multirow{2}{*}{$\begin{array}{l}\text { Source... } \\
\text { Species of ruminant... } \\
\text { Diet... }\end{array}$} & \multicolumn{2}{|c|}{$\begin{array}{l}\text { Present study } \\
\text { Growing sheep }\end{array}$} & \multicolumn{2}{|c|}{$\begin{array}{l}\text { Barry et al. (1981) } \\
\text { Growing cattle }\end{array}$} \\
\hline & Kale & Pasture & Kale & Pasture \\
\hline Dietary $\mathrm{Cu}$ concentration (mg/kg DM) & 4 & 14 & 5 & 14 \\
\hline Dietary sulphur concentration (g/kg DM) & $7 \cdot 2$ & $3 \cdot 1$ & $8 \cdot 0$ & 4.5 \\
\hline $\begin{array}{l}\text { Cu administered to supplemented } \\
\text { groups (mg) }\end{array}$ & 48 & 48 & 300 & 300 \\
\hline $\begin{array}{l}\text { Final liver } \mathrm{Cu} \text { in } \mathrm{Cu} \text {-supplemented animals } \\
(\mathrm{mg} / \mathrm{kg} \text { fresh wt) } \\
(\mathrm{mg})\end{array}$ & $\begin{array}{l}86 \\
57\end{array}$ & $\begin{array}{l}173 \\
187\end{array}$ & $\begin{array}{l}23 \\
89\end{array}$ & $\begin{array}{r}54 \\
214\end{array}$ \\
\hline $\begin{array}{l}\text { Difference in } \mathrm{Cu} \text { retained in liver } \\
\text { between } \mathrm{Cu} \text {-supplemented and control } \\
\text { groups }(\mathrm{mg})\end{array}$ & 33 & 49 & 80 & 202 \\
\hline $\begin{array}{l}\text { (mg) } \\
\text { (Proportion Cu administered) } \\
(\mu \mathrm{g} / \mathrm{kg} \mathrm{W} \text { per } \mathrm{d})\end{array}$ & $\begin{array}{l}15 \\
0 \cdot 31 \\
2 \cdot 7\end{array}$ & $\begin{array}{l}0 \\
0 \\
0\end{array}$ & $\begin{array}{c}208 * \\
0.69 \\
5 \cdot 8\end{array}$ & $\begin{array}{l}98 \\
0 \cdot 33 \\
2 \cdot 8\end{array}$ \\
\hline
\end{tabular}

DM, dry matter; $\mathrm{W}$, live weight.

- Corrected for $13 \mathrm{~kg}$ response in live-weight gain to $\mathrm{Cu}$ supplementation by assuming $1 \mathrm{mg} \mathrm{Cu}$ deposited $/ \mathrm{kg}$ live-weight gain (Agricultural Research Council, 1980).

increasing cytochrome oxidase synthesis (heart) and causing mild liver damage (Barry et al. 1982) may cause an increased turnover of $\mathrm{Cu}$-containing enzymes, all of which could contribute to an increased requirement for $\mathrm{Cu}$.

Despite a higher $\mathrm{Cu}$ requirement for animals grazing kale, it is noticeable that there was no symptom of $\mathrm{Cu}$ deficiency in young sheep grazing this diet for 24 weeks, as judged by muscle cytochrome oxidase levels in control kale-fed animals being similar to those for pasture-fed animals, and by there being no response in live-weight gain or wool growth to $\mathrm{Cu}$ supplementation. The probable reason is the higher true availability of ingested $\mathrm{Cu}$ in brassica species, defined by Suttle (1981) as 0.125 for brassica leaf crops and 0.067 for brassica root crops, compared with 0.02 for ryegrass-clover pasture grown over the summer/autumn period. Thus only mild $\mathrm{Cu}$ depletion occurred in this study when young sheep grazed forage kale for 24 weeks, with the principal responses to injected $\mathrm{Cu}$ (blood SOD; heart cytochrome oxidase) being to counteract haemolytic anaemia.

The authors wish to acknowledge the technical assistance of Mr A. D. Sheppard in conducting the enzyme assays at Wallaceville, and of $\mathrm{Mr} \mathrm{K}$. Turner in determining $\mathrm{Cu}$ and $\mathrm{Fe}$ concentrations at Invermay. Critical reviewing by Dr N. F. Suttle during preparation of the manuscript is gratefully acknowledged.

\section{REFERENCES}

Agricultural Research Council (1980). The Nutrient Requirements of Ruminant Livestock, pp. 221-233. Slough: Commonwealth Agricultural Bureaux.

Andrewartha, K. A. \& Caple, I. W. (1980). Research in Veterinary Science 28, 101-104.

Barry, T. N., Duncan, S. J., Sadler, W. A., Millar, K. R. \& Sheppard, A. D. (1983). British Journal of Nutrition $49,241-253$. 
Barry, T. N., Manley, T. R. \& Millar, K. R. (1982). Journal of Agricultural Science, Cambridge 99, 1-12.

Barry, T. N., Reid, T. C., Millar, K. R. \& Sadler, W. A. (1981). Journal of Agricultural Science, Cambridge 96, 269-282.

Bohenkamp, W. \& Wesser, U. (1976). Biochimica et Biophysica Acta 444, 396-406.

McCord, J. M. \& Fridovich, I. (1969). Journal of Biological Chemistry 244, 6056-6063.

McDonald, I., Mills, C. F., Dalgarno, A. C. \& Simpson, A. M. (1979). Proceedings of the Nutrition Society 38, 59A.

Marklund, W. \& Marklund, G. (1974). European Journal of Biochemistry 47, 469-474.

Mills, C. F. \& Dalgarno, A. C. (1970). In Trace Element Metabolism in Animals, pp. $456-461$ [C. F. Mills, editor]. London: E. \& S. Livingstone.

Minami, M. \& Yoshikawa, H. (1979). Clinica Chimica Acta 92, 337-342.

Misra, H. P. \& Fridovich, I. (1972). Journal of Biological Chemistry 247, 6960-6962.

Smith, R. H. (1974). Report of the Rowett Institute 30, 112-131.

Steven, F. S., Griffin, M. M. \& Smith, R. H. (1981). European Journal of Biochemistry 119, 75-78.

Suttle, N. F. (1976). Chemistry and Industry 559-562.

Suttle, N. F. (1981). In Trace Elements in Man and Animals, Proceedings 4th International Conference, pp. 548-554 [J. C. Howell, J. M. Gawthorne and C. L. White, editors]. Perth, Australia: Australian Academy of Science.

Underwood, E. J. (1977). Trace Elements in Human and Animal Nutrition, New York and London: Academic Press.

Wever, R., Oudega, G. \& Van Gelder, B. F. (1973). Biochemica et Biophysica Acta 302, 475-478. 